American Journal of Applied Sciences 7 (4): 453-458, 2010

ISSN 1546-9239

(c) 2010Science Publications

\title{
Analytical Studies on Water Quality Index of River Landzu
}

\author{
J. Yisa and T. Jimoh \\ Department of Chemistry, Federal University of Technology, Minna, Niger State, Nigeria
}

\begin{abstract}
Problem statement: River Landzu is of particular importance in the study of surface water pollution because effluents from cottage industries, municipal sewage, agricultural and urban run-off are discharged into it bringing about considerable change in the water quality. Approach: This study aimed at using the application of Water Quality Index (WQI) in evaluating the quality of River Landzu for public usage. This was done by subjecting the 120 water samples collected to comprehensive physicochemical analysis using APHA standard methods of analysis. Results: The WQI for the samples was 171.85. The high value of WQI had been found mainly from the higher values of iron, chromium and manganese, COD and turbidity. The results of the analysis when compared with World Health Organization (WHO) and Nigerian Industrial Standard (NIS) permissible limit indicated that the river was polluted and so the water is not safe for domestic use and would need further treatment. Conclusion: The present study demonstrated application of water quality index in estimating/understanding the quality of river water and appeared to be promising in the field of water quality management.
\end{abstract}

Key words: Physicochemical characteristic, water quality index, Bida

\section{INTRODUCTION}

Water is an essential requirement of human and industrial developments and it is one the most delicate part of the environment (Das and Acharya, 2003).

In the last few decades, there has been a tremendous increase in the demand for freshwater due to rapid growth of population and the accelerated pace of industrialization (Ramakrishnaiah et al., 2009). Human health is threatened by most of the agricultural development activities particularly in relation to excessive application of fertilizers and unsanitary conditions (Okeke and Igboanua, 2003). For instance, in most town in Nigeria with rivers passing through them have converted such rivers into dump sites or latrines, with the consequence adverse effects on the health of down stream users. The recent documentary by WHO showing houses, public offices, schools not provided with latrines causing individuals to excrete anyhow in the bushes, rivers and open spaces is a pointer to the extent the Nigerian environment has been deterioted (Okeke and Igboanua, 2003; Egereonu, 2003). This is in addition to the general lack of sanitation by Nigerian Populace.

River Landzu in Bida is of particular importance in the study of surface water pollution because effluents from cottage industries, municipal sewage and agricultural and urban run-off are discharged into the river bringing about considerable change in the water quality. These anthropogenic activities on the river
Landzu pose a serious threat not only to organisms in the river but also the downstream water users. In addition, once the surface water is contaminated, its quality cannot be restored by stopping the pollutants from the source (Ramakrishnaiah et al., 2009). It therefore becomes imperative to regularly monitor the quality of the water and to device ways and means to protect it.

Water quality index is one of the most effective tools to communicate information on the quality of water to the concerned citizens and policy makers. It, thus, becomes an important parameter for the assessment and management of surface water. WQI is defined as a rating reflecting the composite influence of different water quality parameters. WQI is calculated from the point of view of the suitability of surface water for human consumption (Atulegwu and Njoku, 2004).

The objective of the present research is to provide information on the physico-chemical characteristics of River Landzu in order to appreciate the impacts of unregulated waste discharge on the quality of the river as well as to discuss the its suitability for human consumption based on computed water quality index values.

\section{MATERIALS AND METHODS}

Study area: Bida town lies at $9^{\circ} 06^{\prime} \mathrm{N}$ and $6^{\circ} 01^{\prime} \mathrm{E}$ on the Nupe sandstone formation which consists of plains with 
ironstone capped hills or mesas as shown in Fig. 1. The scenery is fairly uniform since lithology and rock structure are not greatly variable. An important feature of the scenery is the existence of large areas of Fadama. The northern edge of the town consists of a broken off plateau. From the foot of two flat-topped hills the townsweeps down into the plain. The town is drained by the Chicen and Mussa streams with the third stream Landzu, which flows right across the heart of the town. The major sources of employment are agriculture and cattle rearing, which engage almost $80 \%$ of the workforce. The major industries are that of cottage, ricemills, stone crushing. Occurrence, movement and storage of water are influenced by lithology, thickness and structure of rock formations. Weathered and fractured granites, granitic gneiss and shale form the main aquifer of River Landzu (Panda et al., 2006).

Ten sampling stations were established along the river course in order to give a comprehensive idea of overall quality of the river, this was monitored for a period of 1 year by taking the sample once in every month. Water samples were collected from the water surface.

Laboratory analysis: Collected samples were subjected to filtration prior to chemical analysis while temperature, $\mathrm{pH}$ and dissolved oxygen were determined in the field. The water samples were then analyzed for 17 parameters: $\mathrm{pH}$, turbidity, refractive index, total hardness, total acidity, total dissolved solids, total solids, chloride, sulphates, phosphate, nitrate, dissolved oxygen, chemical oxygen demand, manganese and iron using standard procedures of analysis (Eaton et al., 1995).

Statistical analysis: The statistical analysis was done for correlation using SPSS 12:0. Water quality index was calculated from the point of view of suitability of the water for human consumption as seen below.

Calculation of WQI: The Water Quality Index (WQI) was calculated using the Weighted Arithmetic Index method. The quality rating scale for each parameter $q_{i}$ was calculated by using this expression:

$$
\mathrm{q}_{\mathrm{i}}=\left(\mathrm{C}_{\mathrm{i}} / \mathrm{S}_{\mathrm{i}}\right) \times 100
$$

A quality rating scale $\left(\mathrm{q}_{\mathrm{i}}\right)$ for each parameter is assigned by dividing its concentration $\left(\mathrm{C}_{\mathrm{i}}\right)$ in each water sample by its respective standard $\left(\mathrm{S}_{\mathrm{i}}\right)$ and the result multiplied by 100 .

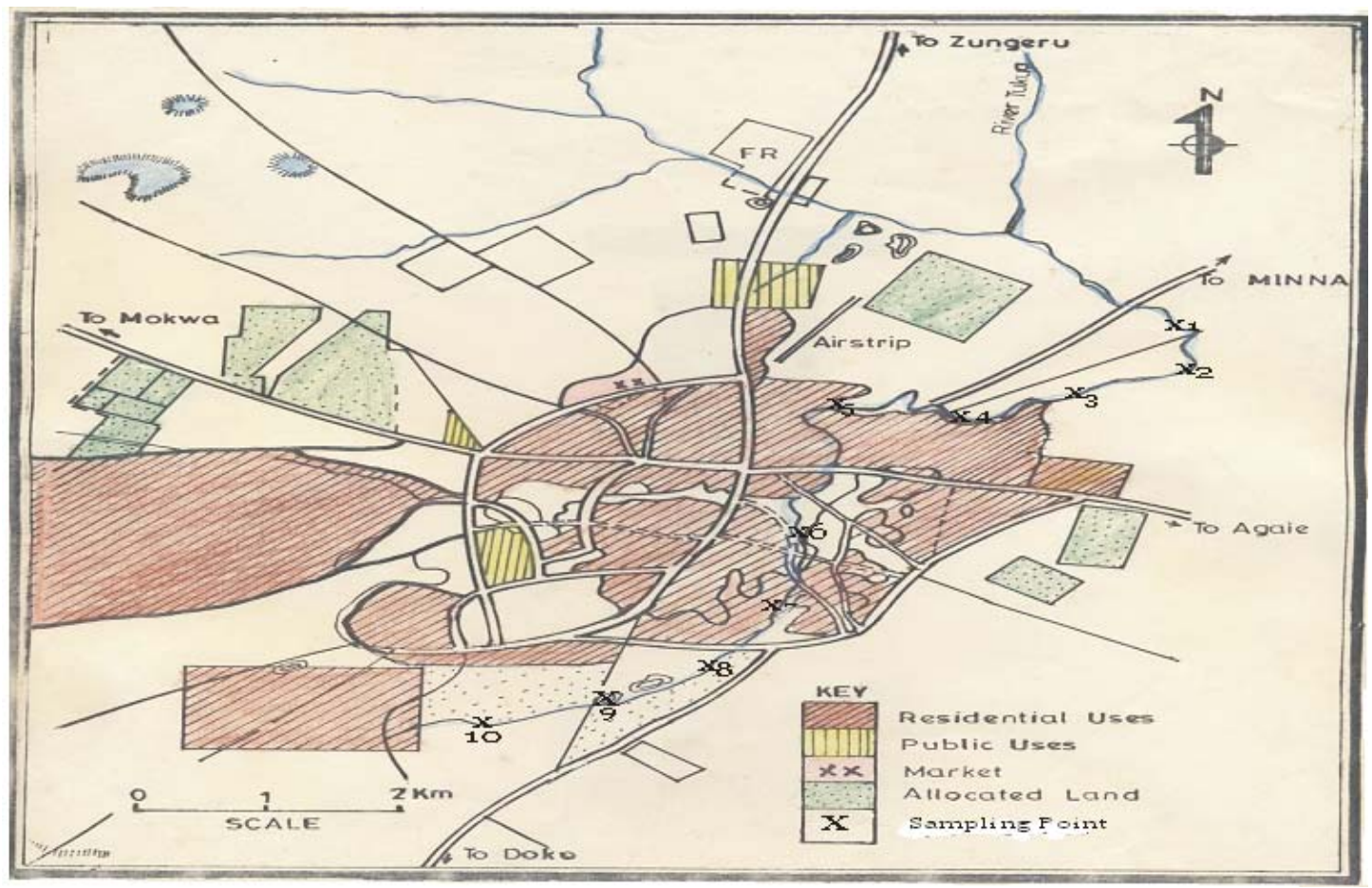

Fig. 1: Map of the area with the location of sampling points (1-10) on the River Landzu a sampling and samples preservation 
Relative weight $\left(\mathrm{W}_{\mathrm{i}}\right)$ was calculated by a value inversely proportional to the recommended standard $\left(\mathrm{S}_{\mathrm{i}}\right)$ of the corresponding parameter:

$$
\mathrm{W}_{\mathrm{i}}=1 / \mathrm{S}_{\mathrm{i}}
$$

The overall Water Quality Index (WQI) was calculated by aggregating the quality rating $\left(\mathrm{Q}_{\mathrm{i}}\right)$ with unit weight $\left(\mathrm{W}_{\mathrm{i}}\right)$ linearly:

$$
W Q I=\left(\sum_{I=1}^{i=n} W_{i} q_{i}\right)
$$

Generally, WQI were discussed for a specific and intended use of water. In this study the WQI for drinking purposes is considered and permissible WQI for the drinking water is taken as 100 :

$$
\text { Overall WQI }=\frac{\sum_{\mathrm{q}_{\mathrm{i}} \mathrm{W}_{\mathrm{i}}}}{\sum_{\mathrm{Wi}_{\mathrm{i}}}}
$$

\section{RESULTS AND DISCUSSION}

The $\mathrm{pH}$ of the aquatic systems is an important indicator of the water quality and the extent pollution in the watershed areas. Results obtained for $\mathrm{pH}$ varied between 6.30 and 6.70 as shown in the Table 1 . The mean $\mathrm{pH}$ value was 6.50. Analytical observation of the $\mathrm{pH}$ values show that metals like Cadmium and Zinc are most likely to have increased detrimental environmental effect as a result of lower pH 6.5 (Davies et al., 2005). However, the $\mathrm{pH}$ concentration in the study area is within allowable limits for surface water (World Health Organization, 1998). The mean turbidity value obtained from the research carried out is $33.50 \mathrm{mg} \mathrm{L}^{-1}$ which is above the standard permissible limits of (Nigerian Industrial Standards, 2003). This could be attributed to presence of organic matter pollution, other effluents, run-off with a high suspended matter content and heavy rain fall (Chapman, 1996).

The mean total acidity value in the study area is above the permissible limits of $100 \mathrm{mg} \mathrm{L}^{-1}$ this might be due to atmospheric deposition of acid-forming substances, industrial effluents whereas the total hardness value of the sample area is within the tolerable limits of (Nigerian Industrial Standards, 2003). Hardness of water causes chocking and clogging troubles of pipelines, causes formation of scales in boilers leading to wastage of fuel and the danger of over heating of boilers (Egereonu, 2004). The hardness of natural waters depends mainly on the presence of dissolved calcium and magnesium salts (Ikomi and Emuh, 2000). The total hardness varies from $33-60 \mathrm{mg}$ $\mathrm{L}^{-1}$ and the values for the study area were found to be within the tolerable limit of WHO specification (World Health Organization, 1998) $300 \mathrm{mg} \mathrm{L}^{-1}$.

Water containing high solids may cause laxative or constipation effects (Egereonu, 2004). The permissible total dissolved salts for drinking water is $500 \mathrm{mg} \mathrm{L}^{-1}$. In the absence of potable water source, the permissible limit is $2000 \mathrm{mg} \mathrm{L}^{-1}$. It is found from the analysis carried out that in all the samples the TDS ranged between 220-1319 $\mathrm{mg} \mathrm{L}^{-1}$. The highest concentration of total dissolved solids was found to be $1319 \mathrm{mg} \mathrm{L}^{-1}$ due to dense residential area and due to intensive irrigation in that area (Egereonu and Nwachukwu, 2005).

Total dissolved solids had concentration range between 700 and $3790 \mathrm{mg} \mathrm{L}^{-1}$. A mean maximum value $1580 \mathrm{mg} \mathrm{L}^{-1}$. The observed high concentration of dissolved solids in the surface water is a pointer to the fact that there are intense anthropogenic activities along the course of the river and run-off with high suspended matter content (Chapman, 1996).

Nitrate and Nitrite are naturally ions that are part of nitrogen cycle. Nitrate ion in water is undesirable. This is because it can cause methaemoglobinaemia in infants less than 6 months old (Egereonu and Nwachukwu, 2005), however, the nitrate value varies from 13.50$15.00 \mathrm{mg} \mathrm{L}^{-1}$. Although all the samples exceed the permissible limit which could be due to leachates from waste disposal, sanitary landfills, over application of inorganic nitrate fertilizer or improper manure management practice (Chapman, 1996). High nitrate levels also leads to eutrophication (World Health Organization, 1998).

Table 1: Physico-chemical properties and calculation of water quality index of Landzu River

\begin{tabular}{lrrr}
\hline & All units are in $\mathrm{mg} \mathrm{L}^{-1}$ except $\mathrm{pH}$ & \\
\cline { 2 - 4 } Parameter & \multicolumn{1}{c}{ Min } & Max & \multicolumn{1}{c}{ Mean } \\
\hline pH & 6.30 & 6.70 & 6.50 \\
Turbidity (NTU) & 31.00 & 37.00 & 33.50 \\
Total acidity & 19.00 & 294.70 & 182.00 \\
Total hardness & 33.00 & 60.00 & 46.90 \\
TDS & 220.00 & 1319.00 & 520.00 \\
Total solids & 700.00 & 3790.00 & 1580.00 \\
Nitrate & 13.50 & 15.00 & 14.30 \\
Nitrite & 0.01 & 0.09 & 0.05 \\
Phosphate & 2.71 & 2.71 & 2.71 \\
Chloride & 22.70 & 37.00 & 31.70 \\
Sulphate & 7.70 & 14.70 & 9.97 \\
DO & 3.10 & 5.20 & 4.20 \\
COD & 51.70 & 102.00 & 80.90 \\
Manganese & 0.57 & 0.84 & 0.74 \\
Chromium & 0.23 & 0.39 & 0.32 \\
Iron & 2.99 & 3.10 & 3.05 \\
\hline
\end{tabular}


The phosphate value obtained is within the tolerable limits. The minimum and maximum value are the same (2.71 $\mathrm{mg} \mathrm{L}^{-1}$ ). The mean concentration value is $2.71 \mathrm{mg} \mathrm{L}^{-1}$ which suggest that phosphorus is rarely found in high concentrations in waters as it is actively taken up by plants. High concentrations of phosphates can indicate the presence of pollution and are largely responsible for eutrophic conditions (World Health Organization, 1998). Domestic waste-waters (particularly those containing detergents), industrial effluents and fertilizers run-off contribute to elevated levels in surface waters.

Chloride is a widely distributed element in all types of rocks in one or the other form (Braide et al., 2004). Its affinity towards sodium is high. Hence, its concentration is high in ground waters, where the temperature is high and rainfall is less. Soil porosity and permeability also has a key role in building up the chlorides concentrations. High concentration of chloride can make water unpalatable and, therefore, unfit for drinking or livestock watering (Egereonu, 2004). High concentration can occur near sewage, irrigation drains, waste outlets. However, the chloride content of the sample was found to be well within the permissible levels of $250 \mathrm{mg} \mathrm{L}^{-1}$, Chloride contents range from $22.70-37 \mathrm{mg} \mathrm{L}^{-1}$.

Sulphates is naturally present in surface water as $\mathrm{SO}_{4}{ }^{2-}$. Industrial discharges and atmospheric precipitation can also add significant amounts of sulphate to surface waters. The mean concentration of the sulphate value is $9.97 \mathrm{mg} \mathrm{L}^{-1}$ which is within the tolerable limits of $500 \mathrm{mg} \mathrm{L}^{-1}$ (Ikomi and Emuh, 2000; Egereonu, 2004).

The mean DO values ranged from 3.10-5.20 $\mathrm{mg} \mathrm{L}^{-1}$. The average value obtained was $4.20 \mathrm{~g} \mathrm{~L}^{-1}$, this indicated that the study area is highly deoxygenated. The low DO concentration could be ascribed to waste discharges high in organic matter and nutrient along the course of the river and probably as a result of the increased microbial activity (respiration) occurring during the degradation of the organic matter (Patnaik, 2005).

The mean concentration of chemical oxygen demand ranged from 51.70-102 $\mathrm{mg} \mathrm{L}^{-1}$. The mean COD concentration in the samples analyzed was $80.90 \mathrm{mg} \mathrm{L}^{-1}$ which indicated that the solids waste is highly polluted with both oxidizable organic and inorganic pollutants (Otukune and Biukwu, 2005).

The value obtained for iron and manganese are equally above the permissible limits $\left(0.57-0.84 \mathrm{mg} \mathrm{L}^{-1}\right)$ and (2.99-3.10 $\mathrm{mg} \mathrm{L}^{-1}$ ) respectively. These elements can lead to coloration of the water thus initiating sedimentation in the system, which can result to corrosion (Egereonu, 2004). In addition, they affect the organoleptic quality of water as do others metals such as copper, aluminum and zinc (Egereonu, 2004).

Chromium ranged between $0.23-0.39 \mathrm{mg} \mathrm{L}^{-1}$. The value constitute health hazard as they are not within the NIS permissible level of $0.05 \mathrm{mg} \mathrm{L}^{-1}$. This must be totally removed from water because they are carcinogenic (Otukune and Biukwu, 2005; Edet and Okereke, 2001):

$$
\text { Overall WQI }=\frac{\sum_{\mathrm{q}_{\mathrm{i}} \mathrm{w}_{\mathrm{i}}}}{\sum_{\mathrm{w}_{\mathrm{i}}}}=\frac{7516.90}{43.74}=171.85
$$

The WQI and overall WQI of all the samples taken were calculated according to the procedure explained above and are presented in Table 2. The results obtained from this study revealed that WQI of Landzu river water is not within the permissible limits (100) from the entire samples taken. The computed overall WQI was 171.85 and can therefore be categorized into five types "excellent water" to "water unsuitable for drinking”. Table 3 shows the percentage of water samples that falls under different quality. The high value of WQI has been found mainly from higher value of turbidity, COD, manganese, chromium and iron in the water sample.

Table 2: Computed WQI values for river Landzu, Bida

\begin{tabular}{lcrrr}
\hline & $\begin{array}{l}\text { Standard } \\
\text { permissible }\end{array}$ & & & \\
Parameter & value $\left(\mathrm{S}_{\mathrm{i}}\right)$ & \multicolumn{1}{c}{$\mathrm{W}_{\mathrm{i}}$} & \multicolumn{1}{c}{$\mathrm{q}_{\mathrm{i}}$} & \multicolumn{1}{c}{$\mathrm{q}_{\mathrm{i}} \mathrm{W}_{\mathrm{i}}$} \\
\hline $\mathrm{pH}$ & $6.5-8.5$ & 0.13 & 86.66 & 11.50 \\
Turbidity (NTU) & 1.00 & 1.00 & 3350.00 & 3350.00 \\
Total acidity & 100.00 & 0.01 & 18200.00 & 182.00 \\
Total hardness & 200.00 & 0.01 & 4690.00 & 23.45 \\
TDS & 500.00 & 0.00 & 52000.00 & 104.00 \\
Total solids & 500.00 & 0.00 & 158000.00 & 316.00 \\
Nitrate & 10.00 & 0.10 & 1430.00 & 143.00 \\
Nitrite & 1.00 & 1.00 & 5.00 & 5.00 \\
Phosphate & 5.50 & 0.18 & 271.00 & 49.27 \\
Chloride & 250.00 & 0.00 & 3170.00 & 12.68 \\
Sulphate & 500.00 & 0.00 & 997.00 & 1.99 \\
DO & 5.00 & 0.20 & 420.00 & 84.00 \\
COD & 10.00 & 0.10 & 8090.00 & 809.00 \\
Manganese & 0.05 & 20.00 & 74.00 & 1480.00 \\
Chromium & 0.05 & 20.00 & 32.00 & 640.00 \\
Iron & 1.00 & 1.00 & 305.00 & 305.00 \\
\hline
\end{tabular}

Table 3: Water quality classification based on WQI value

\begin{tabular}{llc}
\hline WQI value & Water quality & Water samples (\%) \\
\hline$<50$ & excellent & 20 \\
$50-100$ & good water & 36 \\
$100-200$ & poor water & 30 \\
$200-300$ & very poor water & 0 \\
$>300$ & Water unsuitable for drinking & 14 \\
\hline
\end{tabular}


Am. J. Applied Sci., 7 (4): 453-458, 2010

Table 4: Correlation coefficient matrix of water quality parameter

\begin{tabular}{|c|c|c|c|c|c|c|c|c|c|c|c|c|c|c|c|}
\hline & $\mathrm{pH}$ & Turbidity & TA & $\mathrm{TH}$ & TDS & TS & $\mathrm{NO}_{3}$ & $\mathrm{NO}_{2}$ & $\mathrm{Cl}$ & $\mathrm{SO}_{4}$ & DO & COD & $\mathrm{Mn}$ & $\mathrm{Cr}$ & $\mathrm{Fe}$ \\
\hline $\mathrm{pH}$ & 1.000 & & & & & & & & & & & & & & \\
\hline Turbidity & 0.995 & 1.000 & & & & & & & & & & & & & \\
\hline TA & 0.994 & 0.980 & 1.000 & & & & & & & & & & & & \\
\hline $\mathrm{TH}$ & $1.000^{*}$ & 0.994 & 0.994 & 1.000 & & & & & & & & & & & \\
\hline TDS & 0.967 & 0.987 & 0.935 & 0.963 & 1.000 & & & & & & & & & & \\
\hline TS & 0.970 & 0.989 & 0.940 & 0.966 & $1.000^{* *}$ & 1.000 & & & & & & & & & \\
\hline $\mathrm{NO}_{3}$ & 0.999* & 0.991 & $0.998 *$ & $1.000 *$ & 0.957 & 0.960 & 1.000 & & & & & & & & \\
\hline $\mathrm{NO}_{2}$ & $1.000^{*}$ & 0.995 & 0.994 & $1.000^{*}$ & 0.967 & 0.970 & $0.999 *$ & 1.000 & & & & & & & \\
\hline $\mathrm{Cl}$ & 0.989 & 0.970 & 0.999* & 0.991 & 0.919 & 0.924 & 0.994 & 0.989 & 1.000 & & & & & & \\
\hline $\mathrm{SO}_{4}$ & 0.980 & 0.995 & 0.954 & 0.976 & $0.998 *$ & 0.999 & 0.972 & 0.980 & 0.940 & 1.000 & & & & & \\
\hline DO & $1.000 *$ & 0.992 & 0.997 & $1.000 *$ & 0.960 & 0.963 & $1.000 *$ & $1.000 *$ & 0.993 & 0.974 & 1.000 & & & & \\
\hline COD & 0.996 & 0.982 & $1.000 *$ & 0.997 & 0.940 & 0.944 & $0.999 *$ & 0.996 & 0.998 & 0.957 & 0.998 & 1.000 & & & \\
\hline $\mathrm{Mn}$ & 0.989 & 0.970 & $0.999 *$ & 0.991 & 0.919 & 0.924 & 0.994 & 0.989 & 1.000 & 0.940 & 0.993 & 0.998 & 1.000 & & \\
\hline $\mathrm{Cr}$ & 0.997 & 0.986 & $0.999 *$ & 0.998 & 0.947 & 0.951 & $0.999 *$ & 0.997 & 0.997 & 0.963 & 0.999 & 1.000 & 0.997 & 1.000 & \\
\hline $\mathrm{Fe}$ & 0.999 & 0.989 & $0.999 *$ & 0.999 & 0.953 & 0.957 & $1.000 *$ & 0.999 & 0.995 & 0.968 & 1.000 & 0.999 & 0.995 & 1.000 & 1 \\
\hline
\end{tabular}

This could be attributed to improper disposal of wastes, cottage activities, large quantity of agricultural and urban run-off, sewage, over application of inorganic fertilizer, improper operation and maintenance of septic system (World Health Organization, 1998; Chapman, 1996).

The degree of a linear association between any two of the water quality parameters, as measured by the simple correlation coefficient (r), is represented in Table 4. Manganese, Iron and Chromium are highly interrelated among themselves. This interrelationship could depend on environmental conditions, especially oxidation and reduction nature of these elements (Davies et al., 2005). Nitrate and Nitrite are interrelated, this is due to pollution by human or animal waste as well as fertilizer run-off (World Health Organization, 1998; Chapman, 1996; Egereonu and Nwachukwu, 2005). The linear relation between dissolved oxygen and chemical oxygen demand might be attributed to increase in salinity, temperature and biological activity (Otukune and Biukwu, 2005; Patnaik, 2005). Total hardness, Nitrite and dissolved oxygen are also interrelated, the uses of inorganic fertilizers could be a significant source (World Health Organization, 1998). This interrelationship could also indicates that the hardness of the water is permanent in nature (Ikomi and Emuh, 2000).

\section{CONCLUSION}

At the outset, the study clearly indicates that the water of the River Landzu can be used for public consumption without any treatment, however the results obtained from the study reveals that River Landzu is polluted and this could be attributed to anthropogenic activities such as agricultural activities, cottage industries. The WQI of the samples was 171.85 exceeded 100, the upper limit for drinking water.
Application of Water Quality Index (WQI) in this study has been found useful in assessing the overall quality of water and to get ride of judgment on quality of the water. This method appears to be more systematic and gives comparative evaluation of the water quality of sampling stations. It is also helpful for public to understand the quality of water as well as being a useful tool in many ways in the field of water quality management.

\section{REFERENCES}

Atulegwu, P.U. and J.D. Njoku, 2004. The impact of biocides on the water quality. Int. Res. J. Eng. Sci. Technol., 1: 47-52.

Braide, S.A., W.A.L. Izonfuo, P.U. Adiukwu, A.C. Chindah and C.C. Obunwo, 2004. Water quality of Miniweja stream, a swamp forest stream receiving non-point source waste discharges in Eastern Niger Delta, Nigeria. Scientia Africana, 3: 1-8.

Chapman, D.V., 1996. Water Quality Assessment-A Guide to Use Biota, Sediment and Water in Environmental Monitoring. 2nd Edn., ISBN: 041921590, pp: 626.

Das, J. and B.C. Acharya, 2003. Hydrology and assessment of lotic water quality in Cuttack city, India. Water, Air, Soil Pollut., 150: 163-175. DOI: 10.1023/A:1026193514875

Davies, B., M.B. Valente and A. Hall, 2005. The Zambezi Rivers in Mozambique: The physicochemical status of the middle and lower zambezi prior to the closure of the Cobora Bassa Dam freshwater. Biology, 7: 187-189.

Eaton, A.D., L.S. Clesceri, A.E. Greenberg and W.E. Federation, 1995. Standard Method for Examination of Water and Wastewater. 19th Edn., Published by E and FN SPON, Washington DC., ISBN: 0875532233, pp: 8. 
Edet, A. and C. Okereke, 2001. A regional study of saltwater intrusion in Southeastern Nigeria based on the analysis of geoelectrical and hydrochemical data. Environ. Geol., 40: 1278-1289.

Egereonu, U.U. and U.L. Nwachukwu, 2005. Evaluation of the surface and groundwater resources of Efuru River Catchment, Mbano, South Eastern, Nigeria. J. Assoc. Adv. Model. Simulat. Tech. Enterpr., 66: 53-71.

Egereonu, U.U., 2003. Groundwater investigation of Orlu and Onitsha and their environs in eastern Nigeria to ascertain encrustation and corrosion characteristics. J. Assoc. Adv. Model. Simulat. Tech. Enterpr., 64: 33-45.

Egereonu, U.U., 2004. Assessment of atmospheric aerosols from three satellite stations: Heavy metal pollutants. J. Assoc. Adv. Model. Simulat. Tech. Enterpr., 65: 71-88.

Ikomi, R.B. and C.T. Emuh, 2000. The status of the physicochemical hydrology of Upper Warri River Nigeria. J. Sci. Environ., 2: 75-86.

Nigerian Industrial Standards, (NIS), 2003. Standard Organization of Nigeria. NIS 306.
Okeke, C.O. and A.H. Igboanua, 2003. Characteristics and quality assessment of surface water and groundwater recourses of Akwa Town, Southeast, Nigeria. J. Niger. Assoc. Hydrol. Geol., 14: 71-77.

Otukune, T.V. and C.O. Biukwu, 2005. Impact of Refinery Influent on Physico-chemical properties of a water body on Niger Delta. J. Applied Ecol. Environ. Res., 3: 61-72.

Panda, U.C., S.K. Sundaray, P. Ratha, B.B. Nayak and D. Bhatta, 2006. Application of factor and cluster analysis for characterization of river and estuarine water systems-A case study: Mahanadi River (India). J. Hydrol., 331: 434-445.

Patnaik, K.N., 2005. Studies on environmental pollution of major industries in Paradip Area. Ph.D. Thesis, Utkal University, Bhubneshwar, (Unpublished).

Ramakrishnaiah, C.R., C. Sadashivalah and G. Ranganna, 2009. Assessment of water quality index for the groundwater in Tumkur Taluk, Karnataka State. Indian J. Chem., 6: 523-530.

World Health Organization, (WHO), 1998. Guidelines for Drinking Water Quality. 2nd Edn., Geneva, ISBN: 9241545143, pp: 36. 